\begin{tabular}{|c|c|c} 
Eiszeitalter u. Gegenwart & $\mathbf{3 2}$ & $13-22$ \\
& & 3 fig., 1 tab.
\end{tabular}

Hannover 1982

\title{
Neotectonics of a Segment of the San Andreas Fault, Southern California (USA)
}

\author{
Carlos Schubert *)
}

\begin{abstract}
Morphology, neotectonic, San Andreas fault, fault scarp, fault trenche, bassin, sedimentation, alluvium, marshes, peat bog, pond, landform description, Cenozoic, stratigraphic column.

California, Littlerock-Cajon Pass Region
\end{abstract}

A bstract: The San Andreas fault between Valyermo and Wrightwood is characterized by a principal fault trace marked by fault scarps and trenches, tectonic depressions filled with alluvium, marshes, peat bogs, and ponds; displaced and offset drainages, shutterridges and offset ridges, fault gouge zones, fault benches, springs, vegetation contrasts, and trees affected by earthquakes. Secondary fault traces diverge and rejoin the principal trace, and are characterized by lithologic contrast across them, aligned valleys, and fault gouge zones. The minimum right-lateral offset, probably due in part to the 1857 Fort Tejón earthquake, is $20 \mathrm{~m}$; right-lateral offset of drainages and shutterridges ranges between 20 and several hundreds of meters. The distribution of Older Alluvium (Late Pleistocene?) suggests an approximate cumulative right-lateral offset of $3.5 \mathrm{~km}$.

\section{[Neotektonik eines Abschnittes der San Andreas-Verwerfung, Süd-Kalifornien, USA]}

Kurzfassung: Die San Andreas-Verwerfung zwischen Valyermo und Wrightwood ist durch eine Hauptverwerfungslinie charakterisiert, die durch Verwerfungskliffe und -senken und tektonische Depressionen mit Alluvionen, Sumpfland, Torfmooren und Teichen gekennzeichnet sind, ferner durch versetzte und verstellte Abflußrinnen, Querriegel und verstellte Hügel, vertonte Zerrüttungszonen, Stufen, Quellen, Vegetationskontraste und durch von Erdbeben verstellte Bäume. Sekundäre Verwerfungslinien divergieren und konvergieren mit der Hauptverwerfungslinie; bezeichnend für sie sind lithologische Kontraste zu unmittelbar benachbarten Schichten, orientierte Täler und vertonte Zerrüttungszonen. Die relative Rechts-Horizontalverschiebung beträgt mindestens $20 \mathrm{~m}$ und ist wahrscheinlich zum Teil durch das Fort Tejón-Erdbeben von 1857 verursacht. Die Rechtsverschiebung von verstellten Abflußrinnen variiert zwischen 20 und einigen hundert Metern. Die Verteilung des Older Alluvium (Jungpleistozän ?) deutet auf eine kumulative scheinbare Rechtsverschiebung von etwa $3,5 \mathrm{~km}$ hin.

\section{Introduction}

One of the first reports on the San Andreas fault zone in the Valyermo-Wrightwood region (Fig. 1 and 2) was that by NOBLE (1954), who described it as a continuous chain of scarps, ridges, depressions, trenches, and ridges, which cut across northward drainage lines from the San Gabriel Mountains. Numerous subparallel or en e chel o n secondary faults diverge and join the San Andreas fault zone. Within the fault zone there are fault-bounded blocks of Tertiary or pre-Tertiary rocks, which have been raised or depressed. Some of the ridges represent anticlines in Quaternary sediments. Some of the most striking features are the large granitic wedges which have been dragged along or squeezed up. The pre-Quaternary zone of breaking is marked by crushed granitic rock. The recent zone of displacement is marked by deformed younger alluvium.

The San Andreas fault system (fault nomenclature after Crowell, 1975: 10) in the area under study consists of a strip as wide as $32 \mathrm{~km}$ (Fig. 1), and contains a series of faults or strands which branch from and rejoin the San Andreas fault zone (DibbLeE 1968).

*) Adress of author: C. S c h u b e r t, Department of Geological Sciences, University of California, Santa Barbara, CA 93106, U.S.A., and Centro de Ecología, I.V.I.C., Apartado 1827, Caracas 1010A, Venezuela. 


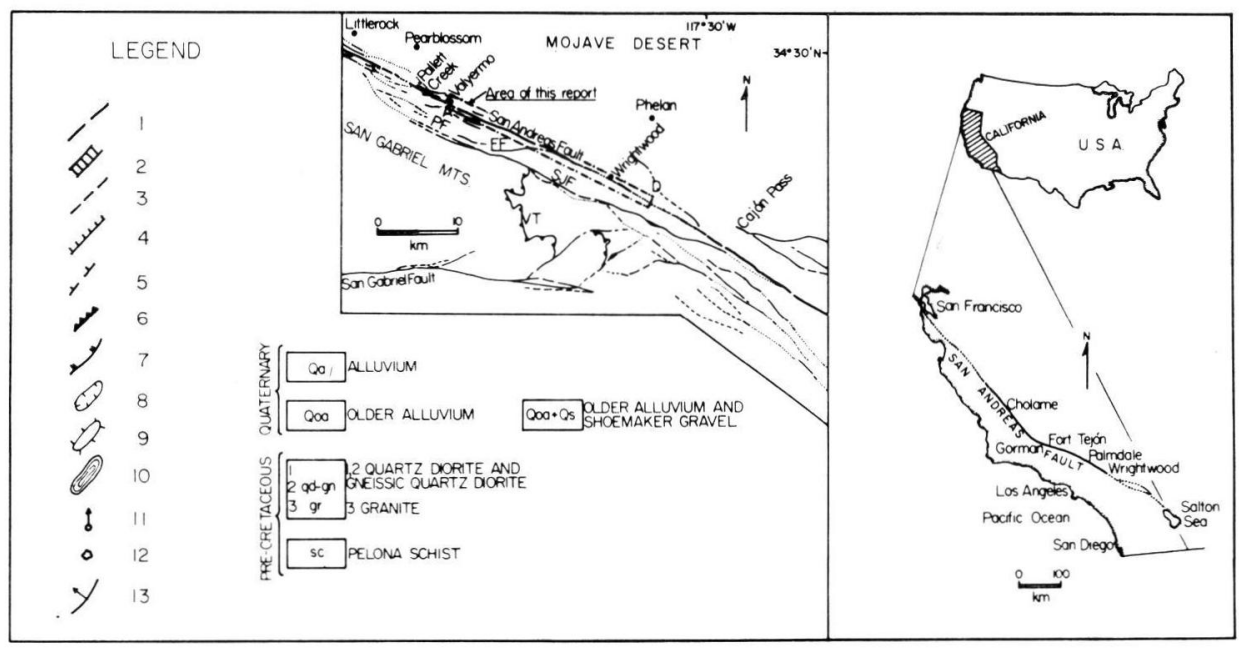

Fig. 1: Index map of the San Andreas fault, generalized fault map of the Littlerock-Cajón Pass region (from Geologic map of California, San Bernardino sheet, Division of Mines and Geology, 1967). The index map shows the approximate rupture length of the 1857 earthquake (SIEH, 1978a). Symbols on the generalized fault map: FF: Fenner fault; PF: Punchbowl fault; SJF: San Jacinto fault; VT: Vincent thrust. Symbols on the neotectonic map: 1. fault exposed in basement rocks; 2. fault zone in basement rocks; 3. fault trace; 4. fault scarp; 5 . poorly developed fault scarp; 6. thrust; 7. landslide scarp; 8 . depression; 9. ridge; 10. sag pond; 11. spring; 12. trees affected by earthquake; 13 . cuesta (arrow in dip direction).

DibbleE pointed out the contrast in pre-Tertiary basement rocks across the San Andreas fault zone. To the south, it consists of Precambrian gneiss, schist, and mylonite, intruded by Precambrian to Mesozoic granitic rocks (anorthosite, gabbro-norite, ferruginous syenite, porphyritic granodiorite), and Mesozoic quartz diorite and quartz monzonite. To the north, the pre-Tertiary basement consists of massive Mesozoic quartz monzonite with Paleozoic roof pendants. The Punchbowl fault (called Nadeau fault to the northwest of the study area), which branches from the San Andreas fault northwest of Palmdale, and follows it in parallel fashion southward, shows no evidence of recent activity, and is interpreted as an old strand of the San Andreas fault, active in Late Pliocene-Pleistocene time (Ehlig 1975). Dibblee (1968) also included the San Gabriel and San Jacinto faults in the San Andreas fault system, and concluded that the cumulative right-lateral slip along these faults, southeast of Gorman, is between 80 and 160 miles (130 and $260 \mathrm{~km}$ ), since Oligocene time. Right-lateral slip along the San Andreas fault and related faults, based on stratigraphic criteria, is listed in Table 1, which shows that uncertainty in displacement measurements increases with age of the stratigraphic unit used, and also the discrepancy between different authors.

The most detailed study of the San Andreas fault zone in the Valyermo area and west is that by BARRows (1979), whose map covers the western third of the map area of this report (Fig. 2). The reader is referred to BARROws' report for the detailed stratigraphy and offset history in that segment. The active trace of the San Andreas fault was mapped and briefly described by Lawson \& OTHERs (1908: 44, Maps 9 and 10). Some of the essential geomorphic features were recognized by these authors and they remarked on the relative scarcity of evidence of recent earthquake-induced features (their report was concerned with evidence of rupture due to the 1906 San Francisco earthquake). 
Most of the recent evidence of displacement along the San Andreas fault has been attributed to the 1857 Fort Tejón earthquake (Wood 1955). A detailed survey of the geomorphic features related to this earthquake was published by SIEH (1978a), who estimated that it had a probable Richter magnitude of $81 / 4$ ( 8.2 as calculated by the regression formula of MARK \& BonILLA (1977) assuming a rupture length of $400 \mathrm{~km}$ ). The geomorphic effects of the earthquake have been recognized between Cholame and Wrightwood (Fig. 1), and rightlateral offset ranges between 3 and $9.5 \mathrm{~m}$. This stretch has been seismically quiet since then, with the exception of the 1916 Fort Tejón earthquake. Microseismicity also has shown low levels, except recently near Palmdale (SIEH 1978a). Microseismicity increases southeast of Wrightwood to a level of one to several events/day $/ 24 \mathrm{~km}$ radius (BRUne \& Allen 1967).

A detailed study of marsh deposits along the San Andreas fault at Pallett Creek (Fig. 2), approximately $3.2 \mathrm{~km}$ west of Valyermo, revealed that eight significant events occurred in this area since the sixth century A. D., with average recurrence intervals of 160 years (SIEH 1978 b).

In this report I describe the neotectonic features of the San Andreas fault in the Valyermo-Wrightwood segment, a segment in which these type of features have not been studied in detail. Aerial photographs were extensively used to trace the neotectonic features identified in the field; offset were measured on aerial photographs and by compass and pacing.

\section{Neotectonic morphology}

Geomorphological evidence for active strike-slip faulting includes such features as scarps, trenches, sag ponds, offset drainage lines, and fault planes with slickensides. Most of these have been recognized and used since the 1906 San Francisco earthquake (LAwson \& OTHERS 1908). The principal drawback in using these features is the difficulty in dating them and, consequently, of dating the fault activity that produced them. As pointed out by ALLEN \& OTHERS (1965), the most important aspect which affects geomorphic fault features is climate. These authors concluded that the "freshness" of these features may be more a function of location than age. In southern California, fault scarps that cut alluvium and offset streams have been assigned to the Holocene; however, evidence has been accumulating which indicates that many scarps are much older, dating even to preWisconsinan time (ALLEN \& OTHERS 1965). Therefore, the use of geomorphic features in mapping active faults can be used only locally for relative dating. Lacking radiometric dates, only detailed loc a l studies of the climatic effect on topographic features in different rocks can provide a relative time depth (s e e, for example, WALlace 1977; BuckNAM \& ANDERSON 1979).

In the Valyermo-Wrightwood segment of the San Andreas fault, which is the southeastern end of the fault stretch which ruptured during the 1857 earthquake, no evidence has been reported of more recent surface activity since then (SIEH 1978a). Seismic activity, as mentioned earlier, has also been low since 1857. Therefore, it can be assumed that the neotectonic morphological features with the freshest appearance in the $30 \mathrm{~km}$ long stretch of the fault studied, particularly those showing the minimum displacement ( 3 to $12 \mathrm{~m}$; SIEH 1978a), were probably produced during the 1857 earthquake.

The neotectonic map (Fig. 2) shows the geomorphic features which are associated with the active trace of the San Andreas fault. These consist of fault scarps, tectonic depressions and ridges, sag ponds, benches, trenches, shutterridges, offset drainages, and triangular facets. All of these are typical geomorphic features which have been recognized and 


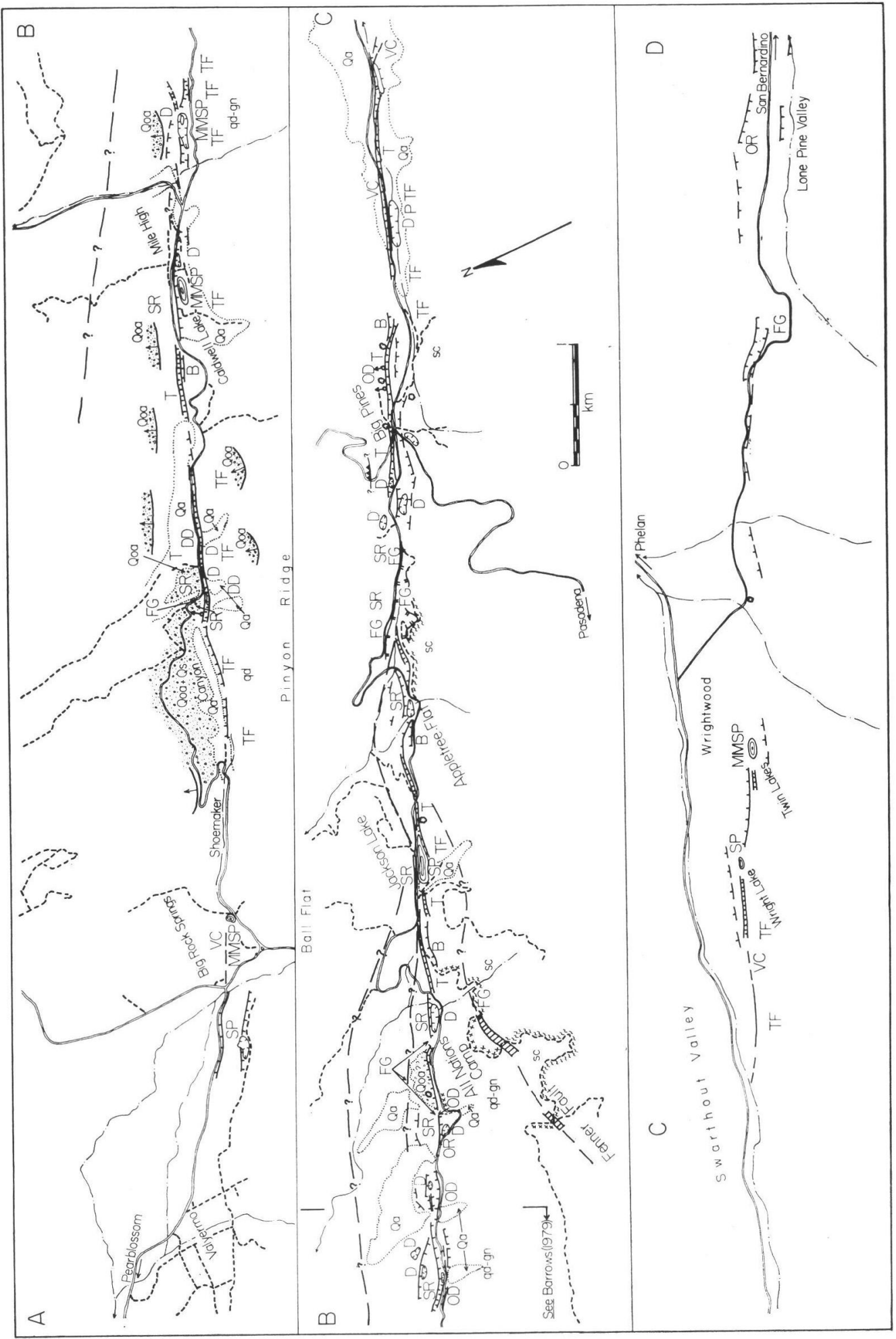


described along the whole extent of the San Andreas fault. In addition, other faultinduced features, such as vegetation contrasts, peat bogs, springs, and trees affected by earthquakes, are shown on the map.

Fault scarps and trenches, and tectonic depressions are the most common fault-induced geomorphic features associated with the San Andreas fault. The typical fault scarp is rectilinear or slightly curved, with a scarp face between $1 \mathrm{~m}$ and more than $20 \mathrm{~m}$ high, and face dips of $20^{\circ}$ to $35^{\circ}$, north and south. Evidences of erosional degradation can be found in rounded scarp crests, gullying, and landslide scars, which modify the scarp. Frequently, there are two scarps forming a step-like, or bench-like feature. The fault trenches consist of linear depressions, usually $10 \mathrm{~m}$ to more than $30 \mathrm{~m}$ wide, $2 \mathrm{~m}$ to more than $20 \mathrm{~m}$ deep, bounded by scarp-like features. Evidences of degradation are similar to those described for scarps. Uninterrupted lengths of scarps and trenches range between a few hundred meters and $4 \mathrm{~km}$. Springs and lines of springs are frequently found within the trenches. Associated with trenches and scarps, there are tectonic depressions filled with alluvium, or containing a marsh, a peat bog, or a pond (sag pond). An excellent example of the latter is Jackson Lake. Other sag ponds have been modified by man to serve as water reservoirs (Caldwell and Twin Lakes). The depressions range from a hole several meters wide and deep, to $0.5 \mathrm{~km}$ long and tens of meters deep. Invariably, they are bounded, at least on one side, by a scarp.

Outcrops of fault gouge are common, particularly in the segment between All Nations Camp and Big Pines. East of Appletree Flat, there is a canyon cut in fault gouge, where the relationship between a fault plane and the fault gouge is exposed (Fig. $3 \mathrm{~A}$ ). At this locality, Pelona schist is in fault contact with sheared, cataclastic granitic rock, which passes into a white, flour-like, fault gouge. The cataclasis is similar to that described by PALMER \& OTHERs (1979). At other localities, such as east of Mile High Ranch, sheared granitic rock crops out as ridges within the fault trench.

Other surficial indications of the San Andreas fault trace are triangular facets, developed mainly on the southern side of the fault, in the steep northern flank of the San Gabriel Mountains (in quartz diorite, gneiss, and Pelona schist); vegetation contrasts, visible on aerial photographs; and saddle-like gaps and notches (Big Pines and east of Wrightwood, at the head of Lone Pine valley).

Along the whole segment of the San Andreas fault mapped, the fault consists of onewell defined trace, marked by the features described above, and several traces which diverge and rejoin the main trace and are parallel or subparallel to it. These strands are marked by fault gouge zones and/or lithologic contrast across them. The Fenner fault, a prominent fault zone up to about $100 \mathrm{~m}$ wide, joins the San Andreas fault from the south at Jackson Lake. This fault clearly separates a quartz diorite-gneiss body to the west from Pelona schist to the east. The fault is characterized by a greenish-gray cataclastic zone, with no evidence of recent displacement.

Fig. 2: Neotectonic map of Valyermo-Wrightwood region, southern California. - B: bench; BC: beheaded creek; D: depression; DD: displaced drainage; FG: fault gouge; MMSP: manmodified sag pond; OD: offset drainage; OR: offset ridge; P: peat bog; SP: sag pond; SR: shutterridge; T: trench; TF: triangular facet; VC: vegetation contrast. Base map: U. S. Geological Survey 15' Quadrangle Maps (Valyermo, Mescal Creek, Mt. San Antonio, and Telegraph Hill). Aerial photographs: U. S. Geological Survey, G. S.-VBZL No. I-189 to -191 , I-194 to -198 , I-225 to -227 . 


\section{Offset along the San Andreas fault}

Right-lateral displacement along the San Andreas fault in the Valyermo-Wrightwood segment, is shown by displaced and offset drainage lines, shutterridges, and offset ridges. The difference between offset and displaced drainage was defined by PATTERson (1979: 130-131): offset drainage is due to strike-slip faulting; displaced drainage (or deflected drainage) may be due to offset, diversion, subsequent erosion, alluviation, lateral corrasion, or damming. Offset drainage may degenerate to displaced drainage due to subsequent erosion and/or alluviation. In the Valyermo-Wrightwood region, this genetic differentiation could only be made in the case of drainage which quite obviously had been affected by strike-slip displacement, such as a series of creeks which stow northward from the San Gabriel Mountains, between Mile High Ranch and All Nations Camp, and which have no continuation north of the fault trace, because they end abruptly against shutterridges. The characteristics of stream channel offsets were discussed in detail by WALLACE (1968).

SiEH (1978a, Table 1, no. 143 to 152) obtained ten offset measurements in the San Andreas fault segment described here. These measurements ranged between $2.0 \pm 0.6 \mathrm{~m}$ and $13.4 \pm 0.9 \mathrm{~m}$ of right-lateral slip, associated with the 1857 Fort Tejón earthquake. According to SIEH's qualitative criteria, the lower estimates generally correspond to poor or fair determinations. This suggests, as shown by WALlACE (1968), that offsets of the order of magnitude of the width of an offset channel are difficult to measure. My own observations in the Valyermo-Wrightwood region confirm this. No clea $r$ drainage offsets or displacements of less than about $20 \mathrm{~m}$ were found. Figure $3 \mathrm{~B}$ shows the geomorphic relationships due to offset of a creek at the head of Shoemaker Canyon. At this locality, a creek flowing north from Pinyon Ridge was offset by the San Andreas fault and was later captured by Shoemaker Creek. The right-lateral offset measured is approximately $211 \mathrm{~m}$, which is certainly due to repeated offset events (44 to 47 events, assuming that the average displacement of 4.5 to $4.8 \mathrm{~m}$, calculated by SIEH $1978 \mathrm{a}$ is typical). The fact that no unequivocal displacement of less than about $20 \mathrm{~m}$ was observed, suggests that erosion and/or alluviation has proceeded at such a rate since the 1857 Fort Tejón earthquake as to obliterate clear drainage offsets due to that event. Only the evidence cited by SIEH (1978a) is indicative of offset related to the 1857 earthquake.

A number of shutterridges and offset ridges were found along the San Andreas fault, particularly in the central part of the mapped segment. All of these consist of pre-Tertiary rocks and indicate right-lateral slip of several hundreds of meters. The shutterridges frequently dammed north-flowing creeks and caused ponding of alluvium.

On the neotectonic map (Fig. 2), a number of possible trees affected by earthquakes are shown. At all these localities, conifers have been tilted, similar to those described by La Marche \& Wallace (1972). The effect on trees by the 1857 Fort Tejón earthquake in the Wrightwood area has been studied by MEIsLing \& SiEH (1979).

From BARRows' (1979) detailed mapping of Quaternary formations in the Valyermo area, it is clear that outcrops of Older Alluvium (Late Pleistocene?) on the south side of the fault trace,are found west of Caldwell Lake; within the fault trace, a p os sible outcrop of this formation is found just northeast of All Nations Camp. This suggests an apparent right-lateral offset of $3.5 \mathrm{~km}$ since Older Alluvium time. More detailed observations have to be made, in particular, measurements of displaced linear piercing structures, to confirm this line of evidence.

No unequivocal evidence of vertical displacement was observed in the mapped area. Several surfaces were observed on aerial photographs, on top of Pinyon Ridge (south 
of the San Andreas fault) and Ball Flat (north of the fault), which may represent a Quaternary (?) erosional surface. The difference in elevation of this surface across the fault is more than $100 \mathrm{~m}$ (south side up).

S
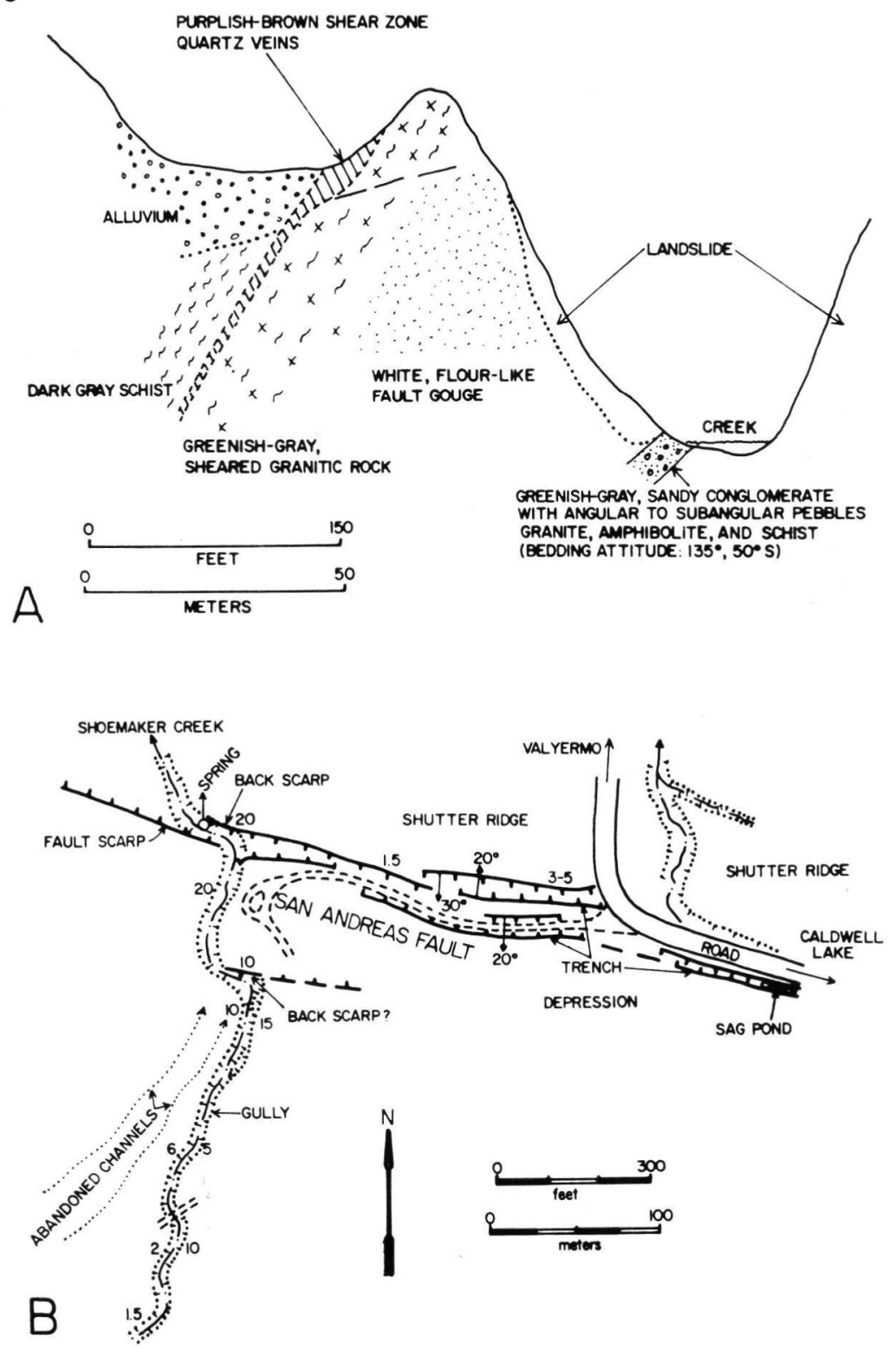

Fig. 3: A) Schematic section across the San Andreas fault approximately $0.8 \mathrm{~km}$ east of Appletree Flat (see Fig. 2). This is the same locality mentioned in IACOPI (1971: 75). B) Geomorphological sketch map just east of Shoemaker Canyon head. Shoemaker Creek has captured a creek flowing north, accross the San Andreas fault, after the latter the creek by approximately $211 \mathrm{~m}$. The numbers without denomination represent the approximate heigths of the fault scarps or gully walls. 


\section{Conclusions}

In the Valyermo-Wrightwood segment of the San Andreas fault, the geomorphic evidence suggests that right-lateral offset ranges from a minimum of $20 \mathrm{~m}$ (probably due in part to the 1857 Fort Tejón earthquake) to several hundreds of meters (displaced drainage and shutterridges). The distribution of Older Alluvium (Late Pleistocene?) suggests a possible apparent cumulative right-lateral offset of $3.5 \mathrm{~km}$. Future studies should include stratigraphic, palynological, and radiocarbon techniques, particularly in peat bogs and sag ponds, to determine a chronology of seismic events. Detailed stratigraphic studies of Quaternary rocks should be oriented towards finding structures suitable for determining fault offset.

\section{Acknowledgements}

Field work in the Valyermo-Wrightwood region was made possible by a sabbatical leave from Instituto Venezolano de Investigaciones Científicas, Caracas, and by the Department of Geological Sciences, University of California, Santa Barbara. It was partially supported by U. S. Geological Survey Grant No. 14-08-0001-17676 (J. C. Crowell, Principal Investigator). I thank J. C. Crowell, A. G. Sylvester, K. E. Sieh, C. R. Allen, and T. Davis for useful discussion. A. G. Sylvester and T. Davis introduced me to the San Andreas fault. J. C. Crowell and A. G. Sylvester reviewed and improved an earlier version of the manuscript. My stay in Santa Barbara would not have been possible without the generous hospitality of BARBARA VOORHIEs.

Tab. 1: Stratigraphically determined right-lateral offset $(\mathrm{km})$ along the San Andreas and related faults, Valyermo-Wrightwood region, California

San Andreas fault Punchbowl-Nadeau faults

Creek channell, before 1857 (4)

Displaced stream gaps (Holocene) (4)

Young gravels (Holocene) (1)

Older Alluvium (Late Pleistocene ?) $(4,6)$

Post-Shoemaker gravel (Late Pleistocene ?) (1)

Late Pleistocene (1)

Shoemaker Gravel (Pleistocene) (1)

Harold Formation (Pleistocene) $(1,4)$

Pleistocene (3)

Quaternary rocks (1)

Juniper Hills Formation (Plio-Pleistocene ?) (1)

Anaverde Formation (Pliocene) (4)

Punchbowl Formation (Upper Miocene) (4)

Tertiary units (1)

Post-Paleocene (5)

Pre-Tertiary basement rocks $(2,3)$

$$
\begin{gathered}
0.16 \\
>1.6 \\
1.5 \\
1.1-3.2 \\
3.5 \\
3-5 \\
16 \\
7-8 \\
3.2-8.0 \\
15 \\
32-40 \\
8 \\
20-21 \\
56 \\
48 \\
16 \\
\\
80-96 \\
128-256 \\
208 \\
240
\end{gathered}
$$

50

48

Sources: 1. Barrows (1975, 1979); 2. Dibblee (1968); 3. Ehlig (1975); 4. Noble (1954); 5. SAGE (1975); 6. This report. 


\section{References}

Allen, C. R., St. Amand, P., Richter, C. F. \& Nordquist, J. M. (1965): Relationship between seismicity and geologic structure in the southern California region. - Seism. Soc. Am. Bull., 55: 753-797; Berkeley.

Barrows, A. G. (1975): The San Andreas fault zone in the Juniper Hills quadrangle, southern California. - In: Crowell, J. C., ed.: San Andreas fault in southern California. - Calif. Div. Mines and Geol., Sp. Rep. 118: 197-202; Sacramento.

- (1979): Geology and fault activity of the Valyermo segment of the San Andreas fault zone, Los Angeles County, California. - Calif. Div. Mines and Geol., Open File Rep. 79-ILA: 1-49; Sacramento.

Bucknam, R. C. \& Anderson, R. E. (1979): Estimation of fault scarp ages from a scarp-height slope-angle relationship. - Geology, 7: 11-14; Boulder.

Brune, J. \& Allen, C. R. (1967): A micro-earthquake survey of the San Andreas fault system in southern California. - Seism. Soc. A., Bull., 57: 277-296; Berkeley.

Crowell, J. C. (1975): The San Andreas fault in southern California. - In: Crowell, J. C., ed.: San Andreas fault in southern California. - Calif. Div. Mines and Geol., Sp. Rep. 118: 7-27; Sacramento.

Dibblee, T. W. (1968): Displacements on the San Andreas fault system in the San Gabriel, San Bernardino, and San Jacinto Mountains, southern California. - In: Dickinson, W. R. \& Grantz, A., eds.: Proceedings of conference on problems of San Andreas fault system. Stanford Univ. Pubs. Geol. Sci., 11: 260-277; Stanford.

- (1975): Tectonics of the western Mojave Desert near the San Andreas fault. - In: Crowell, J. C., ed.: San Andreas fault in southern California. - Calif. Div. Mines and Geol., Sp. Rep. 118: 155-161; Sacramento.

EhLig, P. L. (1975): Basement rocks of the San Gabriel Mountains, south of the San Andreas fault, southern California. - In: Crowell, J. C., ed.: San Andreas fault in southern California. Calif. Div. Mines and Geol., Sp. Rep. 118: 177-189; Sacramento.

IACOPI, R. (1971): Earthquake country. - 160 p., Menlo Park (Lane Books).

La Marche, V. C. \& Wallace, R. E. (1972): Evaluation of effects on trees of past movements on the San Andreas fault, northern California. - Geol. Soc. Am. Bull., 83: 2665-2676; Boulder.

Lawson, A. C. \& othens (1908): The California earthquake of April 18, 1906. Report of the State Earthquake Investigation Commission. - 461 p., Washington (Carnegie Institution of Washington).

Mark, R. K. \& BoniLla, M. G. (1977): Regression analysis of earthquake magnitude and surface fault length using 1970 data of Bonilla and Buchanan. - U. S. Geol. Surv., Open File Rep. 77-614: 1-8; Menlo Park.

Meisuing, K. E. \& SieH, K. E. (1979): The effect of the 1857 Fort Tejón earthquake on trees near Wrightwood and Frazier Park, California. - Geol. Soc. Am. Abstracts with Programs, 11: 478; Boulder.

Noble, L. F. (1954): The San Andreas fault zone from Soledad Pass to Cajón Pass, California. - Calif. Div. Mines Bull., 170: 37-48; Sacramento.

Palmer, D. F., Anderson, J. L. \& Osborne, R. H. (1979): Petrogenesis of cataclastic rocks within the San Andreas fault zone of southern California. - Geol. Soc. Am. Abstracts with Programs, 11: 491; Boulder.

Patterson, R. G. (1979): Tectonic morphology and neotectonics of the Santa Cruz island fault, Santa Barbara Country, California. - M. A. thesis, 141 p, Santa Barbara (University of California).

SAGE, O. (1975): Sedimentological and tectonic implications of the Paleocene San Francisquito Formation, Los Angeles County, California. - In: Crowell, J. C., ed.: San Andreas fault in southern California. - Calif. Div. Mines and Geol., Sp. Rep. 118: 162-169, Sacramento.

SIEH, K. E. (1978a): Slip along the San Andreas fault associated with the great 1857 earthquake. - Seism. Soc. Am. Bull., 68: 1421-1448; Berkeley.

- (1978b): Prehistoric large earthquakes produced by slip on the San Andreas fault at Pallett Creek, California. - Jour. Geophys. Res., 83: 3907-3939; Washington. 
WALLACE, R. E. (1968): Notes on stream channel offset by the San Andreas fault, southern Coast Ranges, California. - In: Dickinson, W. R. \& Grantz, A., eds.: Proceedings of conference on geologic problems of San Andreas fault system. - Stanford Univ. Pubs. Geol. Sci., 11: 6-21; Stanford.

- (1977): Profiles and ages of young fault scarps, north-central Nevada. - Geol. Soc. Am. Bull., 88: 1267-1281; Boulder.

Wood, H. O. (1955): The 1857 earthquake in California. - Seism. Soc. Am. Bull., 45: 47-67; Berkeley.

Manuscript received on 15. 1. 1982. 